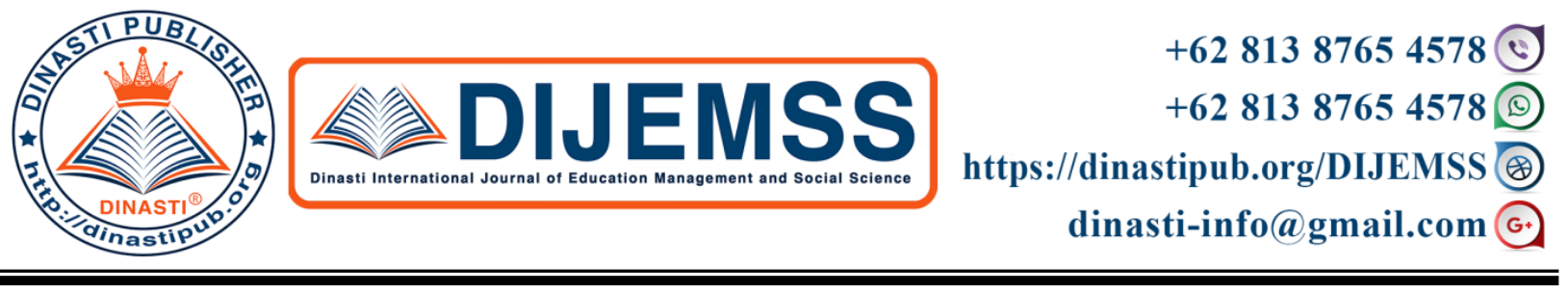

\title{
DYNAMICS OF CHARACTER EDUCATION THROUGH THE OUTBOUND TRAINING ACTIVITIES FOR STUDENTS ON THE CAMPUS
}

\section{Ryan Firdiansyah Suryawan ${ }^{1}$, Dewi Dyah Widyastuti ${ }^{2}$}

1) ${ }^{2)}$ Sekolah Tinggi Penerbangan Aviasi, Jakarta Selatan, Indonesia

ARTICLE INFORMATION

Received: 01 ${ }^{\text {st }}$ April 2020

Revised: $20^{\text {st }}$ April 2020

Issued: $29^{\text {th }}$ April 2020

Corresponding author:

Ryan

E-mail:

ryan.firdiansyah.1979@gmail.com

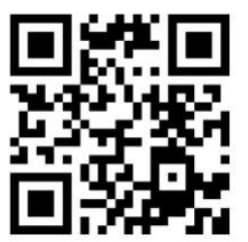

DOI:10.31933/DIJEMSS
Abstract: This research uses qualitative descriptive method by taking the results of the implementation of the data that has been unsettled outbound management training activities where researchers are also lecturers as Chairman of the Committee in the activities of outbound management training in aviation aviation high school jakarta, both using the method of the study of literature to support the data in the discussion. The results of this research: response to these conditions, AVIATION flight College help participate in back, straighten and encourage positive behavior through character education so that graduates into a human who has a soft skill and skill that is difficult. Character education for flight school students carried out off-campus in the open in the form of training that includes a variety of outbound activities management training by type of training provided is the emergency aircraft, the formation of water, the life craft, landing nets and hoist outbound Please. The purpose of education is to form character and cultivate good behaviour or attitude and value so that they can interact, communicate, and live together in accordance with the norms of the community. Tangible results seen from students who have undergone study. Through outbound training, it is expected that students can mentally ready, tenacious, confident, caring, helpful and accountable to God Almighty, self, community and nation that are implemented in real life everyday.

Keywords: Character Education, Outbound Management Training Method 


\section{INTRODUCTION}

A question of character building is still a major issue, even a very large. All the corruption we feel now is born out of the lack of a solid enough figure on ourselves together. The character of the nation's fragile and human character of Indonesia easily falter. Presumably, the number of people who honestly is still pretty much in Indonesia, but they are not powerless faced small groups of human beings corrupt Indonesia, which has the power or rides along on power. Moral depravity, disobedience to the law, the culture (Customs), violations of ethics, and many others we meet in our own environment. Many areas of education have been underestimated by thinking fuzzy, low standards, and the mentality of the feel-good, whatever. Character education is no exception. (Damon, William, 2001). The importance of character education for students will give a pembamding to them that in addition to formal education, then education character it had something special they can show and count on.

In my visits to schools around the country, I have seen a lot of lip service is paid to the "nice values " and many in-depth program that asks students to utter words of wisdom like frankness, simplicity, and respect. I have also seen the consenting adults promoting behavior that should have their say against children. I have heard the teacher told students that they are not blaming them for cheating on a test that is unfair or meaningless. I have heard about sex education programs that instruct students in the use of contraceptives. I've been observing adults who advise minors of alcohol abuse by telling them to remain within the limits of one drink per hour, ambivalent messages that kind of make fun of character education. (Damon, William, 2001).

Figures like this is what may need to be addressed, nurtured, and reformed, so that it would become the nation's character. It is necessary to have ways to build character as early as possible, which can be done through the education in the family, schools, in College, and/or in the neighborhood association. Jonathan Cohen argues that the purpose of education need to be framed to prioritize not only academic learning, but also the competence of social, emotional, and ethical. Surveying the State of current research in the field of education social emotional, character education, and school-based mental health in the United States, Cohen indicated that the skills, knowledge, and social-emotional disposition provides Foundation for participation in democracy and the improvement of quality (cohen. 2006). Life Viewed such figures (Flight AVIATION high school (STP aviation) strives to prepare its student in order to have good character that can be developed within the general public as well as his life in aviation society .

Cohen discusses the contemporary best practices and policies in connection with creating a climate that is safe and caring school, school-home partnerships, and pedagogy informed by social-emotional concerns and ethics. He also stressed the importance of the steps that a scientifically logical from the social-emotional learning and ethical, and advocate fo $r$ action research partnerships between researchers and practitioners to develop authentic evaluation methods. (Cohen, 2006). Character education can be divided into two main genres: indirect and direct, with the main emphasis on the assimilation of culture and the importance of social 
interaction. Camp indirect assimilation (often feminists) generally advocate the social aspect of moral education and the importance of narrative, dialogue, and language acquisition. (Duncan, Barbara, 1997).

The key moment in the social scientific theory of moral development and education of the 20th century have included (1) the claim of Durkheim that autonomous compliance against some consensual conception of public social welfare is required to maintain cohesion in the civil the graduate society of religion or sekuler2; (2) other Freudian psychoanalysis and the location of the origin of moral awareness in the early psychological conflict and repression mechanism; (3) attempts to understand the moral formation of behaviorists in connection with responseconditioned response (socially) against stimulus; and (4) breakthrough effort Jean Piaget to give an account of cognitive development of moral considerations and considerations. 3 with a clear intellectual debt to early development like that, it is also possible to distinguish-roughly from the end of the World War II until the dawn of the twenty-first century-the emergence of three trends of moral education which is quite different. (Carr, David, 2007).

Implementation of character education in the community using the Bordentown "comprehensive " model, meaning that the program covers all issues related to value. It is comprehensive because it also happened in the entire school system, including school buses, a playground, and all extracurricular activities. (Fisher, Shirley, 1998). To build student character, other than obtained in the classroom are also formed when they became freshmen. The formation of these characters executed in fresco off campus with the term Outbound Management Training (OMT), which was set aside at the aerospace activities are Outbound. (DOB handbook, 2006), this training Program is intended to provide and develop potential include: confidence, motivation, loyalty, a willingness to act, energy, honesty, intelligence, reliability, self development, stability in the its environment.

As for the purpose of the implementation of the training is to build up the courage and self-confidence, improve themselves, train working group and Intergroup, balanced in terms of mental and physical, to melt the ice, build synergy and mutual believe, and can dig up each personal ability A survey of research on moral education revealed the eight characters of the characters discussed in the education program character: compassion, respect, discipline, loyalty, courage, responsibility, forgiveness, and justice (Andrews, 1993; Huffman, 1995; Lickona, 1991; Ohio State) (Leal, Dorothy J, 1999).

This research aims to inform and discuss on the activities of Outbound Management Training in the creation of the character of the students that have been implemented by the STP flight AVIATION campus in Jakarta. The character was the hallmark of inherent in the individual, family, and community. The character is consistent and predictable tendency is shown by behavior. (lapsey, DK \& Narvaez, D, 2006). Character education, the concept of the development of moral awareness in students (Lickona, 1999). Martens (2004) explains that there are three stages that need to be done in character education, namely identification of th e value, the value of learning, and provides an opportunity to implement those values. 
Outbound Management Training Outbound/outwarbound cruise is a term used in th e past at the time of sailor left the Harbour to the sea which is full of uncertainty (DOB Handbook, 2006) possibilities can occur the sea conditions were very different in the land. Therefore, they are trained and are constructed to be self- learning, eliminating fear, more confident, not dependency, and dared to take the decision to act. Outbound management training activities conducted to STP students AVIATION Aerospace is the share in it covers a wide range of activity areas of aerospace such as aircraft emergency, formation in the air, the game boats (lifecraft), landing nets, and rescue hoist.

Training methods emphasizing dialogue, on the practice field, and guidance as well as interviews designed to take advantage of the natural sedagai challenges the mainstream media; Games (games) are designed as problematic in the wild for planned, analyzed, and solved together; discussion and practical applicative study of intellectual quotient (IQ), emotional intelligence (EQ), spiritual intelligence (SQ); helper tools and instructional and instructional tools. Aviation Flight Jakarta high school as a place of research data retrieval is already implementing training outbound management training over the last twelve years, outbound management training training conducted at the aviation high school Aviation is to form character, camaraderie, cohesiveness, know each other and cooperation between students of the early campus entrance yet salaing know. Outbound management training training conducted by Aerospace Outbound which is an existing national training institutes in Indonesia. Outbound training types used in high school Aviation Flight Jakarta, among others;

Aircraft Emergency, this training is a form of self rescue (passengers) from a plane crash. This activity aims to train students in dealing with emergency situations in aircraft to immediately get out of the plane ... After students wear exercise equipment, through the aba ab ainstructor (as a replacement for the function of steward/stewardess) student walking squat then slid when the door of the aircraft and slidding open.

The formation of water, this training is a form of escape from danger in the midst of the sea/waterways or on land far from any help with the formation of stars in order to be seen from a plane passing by with a view to informed that there had been an accident. The purpose of this activity is to improve the responsiveness and reaction quickly to emergency situations in order to immediately get help.

Boat games (Lifecraft), this training is a form of escape and survival in the water/sea using boats be reversed in order to protect themselves from sunburn, storms, wind, or other hazards. The purpose of this training is to build up the mental strength to stay calm and can survive in water/seas until help came.

Landing nets, this training is a form of self rescue in a way up the ladder webs that unfolds in a helicopter or ship by way of slowly rising to the position of the Agency docked onto the ropes while the edging upwards.

The purpose of this training is to develop self rescue capabilities by way of a climbing rope.Rescue Hoist, similar to the shape of the mesh on top but this aid with a large hook tool 
which can travel by two or more persons are then drawn in by helicopter. Either the net or hoist function is to rescue victims from the accident. The purpose of this research is to inform and share experience from one of the flight school that is high school Aviation Flights Jakarta using the method of the formation of character with a using Outbound Management Training.

\section{RESEARCH METHODS}

The research uses qualitative descriptive method by taking the results of the implementation of the data that has been unsettled outbound management training activities where researchers are also lecturers as Chairman of the Committee in the activities of outbound management training in aviation aviation high school jakarta, both using the method of the study of literature to support the data in the discussion.

\section{FINDINGS AND DISCUSSION}

In the 29 chapters, education, psychology, and other scholars from the U.S., Asia, Canada, Europe, and Australia discussed aspects of moral and character education. They describe the Foundation of historical, philosophical, and theoretical in the field, including the dimensions of the ethics of teaching; theory-based approaches such as cognitive social domain theory, the use of the theory of attachment and self-determination theory in the development of the discipline approach, constructivist approach, and the approach of a fair community; examples of school-based best practices for different types of students; moral education in relation to civic engagement and citizenship and democracy education (new section); and moral education and character outside the classroom in relation to society, learning services, the development of adolescents who are positive, and other fields. (ProtoView; Beaverton, 2014)

Starting from the vision, mission, goals, and objectives STP AVIATION, there are great expectations of this College who participated in the enlightened Nations of course are expected graduates have competency cognitive, affective, and psychomotor. Character education is very necessary to build the character of the students, as though already a teenager who stepped on adults (students) sometimes appears behavior-behavior that is less good, arrogant, or less ethical, less acceptable by the community.

According to the psychology of adolescents, in this time there is a contradiction in his soul against the incoming impulses and contrary to the values that are in themselves are not necessarily correspond to the value (value) is universally that is in environment of the community. In this case the character education is indispensable also in a college environment through mentoring in the classroom and outside the classroom so that students know more about the value (value). The character is a combination of morals, ethics, and morals. More emphasis on the quality of moral deed, action or human behavior or whether deeds could be said to be good or bad, or right or wrong. Instead, the ethics of giving judgments about good and bad, based on the norms applicable in a particular community, while morals tatanannya more stresses that in fact in 
man it has ingrained beliefs in which both (good and bad) it exists. (Litbangkemdiknas, Kemendiknas, 2006).

Character education brings students to the introduction in the cognitive, affective, generally penghayatan nilai finally into practice in the real's value. (M. Buchori, 2007). It is intended that the skill and cognition is not enough to form a human character, must be equipped with values that is affection. Human character is a person who has a typical values either hardwired in themselves and form in the behavior. The traits of good character people according to Aa Gym, namely those who have honest sifar, caring, fairness, responsibility, iklas, generous, tawadhu (humble), glad to help.

At the moment it is difficult to find teens/adults who have characters as mentioned by Aa Gym. Therefore, to develop the character needs to be nurtured through character education/characters through formal education, non-formal and in formal. Looking at the trend of social interaction and life conditions of the teenagers who was further away from the norms in force in the community, in addition to the responsibility of parents is also the involvement of stakeholders in restoring the correct social life including the institution strives to build culture and form a positive character so that they have a moral, ethical, morals are either through character education. Character education is meant as educational value, character education, moral education, character education, which aim to develop the ability of learners to give decisions baik-buruk, keep what's good, and it embodies the kindness in everyday life with a vengeance.

The popular term is currently to form HUMAN RESOURCES who are ready to live the world of work in addition to having a hard skill also soft skills. Based on the data which was adopted from Havard School of business, the abilities and skills that are given on the bench learning, $90 \%$ is the technical ability and the rest soft skill, though, who needed to face the working world that is only about $15 \%$ of the capabilities of the hard skill. (Hafis Mu'addab, 2010). Thus, the soft skills that are needed in the industry. Is a soft skill is "Personal and interpesonal behaviors that develop and maximize human performance (e.g., coaching, team building, decision making initiative, etc.) Soft skills does not include technical skills such as financial, computing and assembly skills ". (Berthal). Softskills is someone's skills in dealing with other people (including himself).

Attributes of soft skills, thus encompassing the values embraced, motivation, character, habits, behavior and attitude. Attributes of soft skills is owned by everyone with different levels, influenced by habitual thinking, say, Act and behave. However, these attributes can be changed if the concerned want to change this way ofpracticing familiarize yourself with things that are new, Whereas hard skill is "processes, procedures, industry specific jargon and are easy to measure and quantify. They are terms such as; account management, talent acquisition and development, client retention, data management, project management, accounts receivable and payable, product support, and new business development "(Jessica Hollbrook). Hard skills is the mastery of the science, technology, and technical skills related to the field of science. 
Very easy to measure the success of hard skill rather than soft skill, nevertheless remains the campus as educational institutions embody the desired skills workforce while simultaneously building the nation character. Outbound as Character Building, formation of character (Character Building) is defined as a process to form, nurture, familiarize do attitudes and behavior-behavior that good or that have a value (value) in order to interact, communicate, and live together in accordance with the norms that exist in society. Character Building is build personal character-a tough, personal integrity, and noble character (Erie sudewo, 2011), while according to Febechen, the Character Building is doing anything with maximum power and do not need to disputed results, the key is to achieve excellence-excellence located on developing habits of success. (Febechen, 2009)

As already described in the future that the outbound training is off-campus activities (outdoor) that aims to train students to have strong mental and behavior building (characters) that are either in accordance with the norm of life in the community. (Akhmad Sudrajat, 2010) that extra-curricular activities organized during this school is one of the medium's potential for fostering character and increased the quality of academic learners. (Akhmad Sudrajat, 2010) Cocurricular activities is educational activities outside school subjects to help the development of the learners according to the needs, potential, talents, and interests th em through activities specially organized by educators and or capable of produce educators and berkewenangan at the school. Through co-curricular activities are expected to develop the ab ility and sense of social responsibility, as well as the potential and the achievements of learners. outbound there are elements of the development of creativity, communication, effective listening, teamwork, self motivation, competition, problem solving and confidence. (Adrian and Yufiarti 2006:44).

These activities are designed specifically for new students is carried out before they carry out the lectures as forms of activities orientation courses conducted for two days one night with a variety of activities that are already mentioned in the the previous page. The training of the various looks of some of the benefits that can be obtained for the students fo $r$ life now and will come when interacting with the physical environment as well as the social environment.The benefits gained are deficiency and excess Understand themselves so that each can give rise to trust in yourself and understand that he has lacked in a lecture here, or be in response face the problem and try hard looking for a way out as soon as possible with the help of another person, or Be indifferent towards their fellow and its surroundings (not be apathetic and have an attitude of tolerance), foster a sense of wanting to help/help to others in distress with the capabilities of myself or done in a group, learn to take charge of th emselves and their social environment, build camaraderie and cohesiveness of the Intergroup, abide by the rules defined as the code of conduct, procedures hours lectures, attendance at classes and more.

Some of accomplishments this is character education (ahmad Sudrajat, 2010), comply with the rules applicable in the social environment, appreciate religious diversity, cultural, tribal, racial, and socioeconomic groups within the scope of national, demonstrate the ability of logical thinking, critical, creative, and innovative, demonstrate the ability to analyze and solve problems 
in daily life, describe symptoms, utilizing the natural and social environment are responsible, applying the values of community life in community, nation, and State for the sake of national unity in the unitary State of the Republic of Indonesia, and to communicate and interact effectively and manners.

Character development can be done in the classroom as well as in the campus environment with, among others, abide by and implement rules applicable academic rules or ru les of the Association. Students must know and understand the rules (to know/to learn) so what would he do not deviate. For example about the concern of students against the campus environment. The cleanliness and beauty of the campus can be done with no butts, beverage bottles, paper, and other small waste in any place though in the vicinity has already placed the trash. Glue the writing on the wall that reads: "keep the cleanliness", "nonsmoking" it is expected that students obey the rules. Adherence to the rules will appear when they do (to do). But these actions must be conditioned, for that character is formed th rough conditioning. Conditioningconditioning is what will shape the human character (to be). Thus, the character who awakens will be very useful in the life of socialising andinteracting with the environment his life (to live together). The example above shows a social care based because a sense of responsibility to themselves as well as the social environment. After a lengthy discussion of the source of getting the references before then in the implementation of character education at the high school of aviation flight from jakarta using outbound management training by describing that flight schools in the implementation of the above activities is already thinking about the impact of the exodus of students to the new entry by following the bealajar process by which creation capabilities that represent hard and soft skill skil.

Based on the curriculum, the ability of hard skill easily in its accomplishments, yet another thing with the achievement of soft skill that need coaching andconditioning. Coaching can be done in the classroom (teaching-learning process) or outside of the classroom (outbound training) with a wide range of activities in it and its implementation can be carried out in daily life. The real implementation of the campus is the existence of discipline, and the regulations of the campus.

Besides, it student who have been following the activities of outbound management training is continuously continuously provided coaching and be reminded in the learning process during the lecture. The activities of student character formation through outbound management training provide a positive impact for students and has been used from year 2006 up to now. This result is describe in the real existing flight aviation high school in jakarta.

\section{CONCLUSION AND SUGGESTIONS}

In the creation of graduates as human resources have the ability of hard and soft skill skil that comply with the conditions of its environment is certainly required coaching to form both the capability. Based on the curriculum, the ability of hard skill easily in its accomplishments, yet another thing with the achievement of soft skill that need coaching and conditioning. 
Coaching can be done in the classroom (teaching- learning process) or outside of the classroom (outbound training) with a wide range of activities in it and its implementation can be carried out in daily life.

The efforts made for the establishment of the character as a coaching process initiated through outbound training activities in the outdoors is carried out on a new student orientation events with the aim of setting up a student or HR has attitude- good behavior. For the construction of the next is get used to doing something positive that can be applied on campus; for example, by complying with existing regulations.

To help confront and fostering behaviour (character) nation that little by little began to shift, high school of Flight Aviation Jakarta already run the program outbound management training was connected with the establishment of the characters of college students in the face of successful learning and could make the references.

The results of this research provide an overview and also led to another discussion regarding the same matter on deliberations of the character education and outbound management.

\section{REFERENCE}

Akhmad, Sudrajat. 2010. Konsep Pengambilan Keputusan Dalam Manajemen Pendidikan. Http://Akhmadsudrajat.wordpress.com. Diakses Tanggal 4 November 2015 Cohen, Jonathan. Social, Emotional, Ethical, and Academic Education: Creating a Climate for Learning, Participation in Democracy, and Well-Being.Harvard Educational Review; Cambridge Vol. 76, Iss. 2, (Summer 2006): 201-237,285.

Damon, William. Character education the right way Commentary; New York Vol. 111, Iss. 3, (Mar 2001): 0_3.

Dirgantara Outbound, Handbook, LPP Sekolah Tinggi Penerbangan AVIASI, 2006.

Duncan, Barbara, Character education: Reclaiming the social, J.Educational Theory; Urbana Vol. 47, Iss. 1, (Winter 1997): 119.

Erie Sudewo. 2011 Best Practice Character Building Menuju Indonesia Lebih Baik. Jakarta : Republika Penerbit. Fisher, Shirley. Developing and implementing a K-12 character education program Journal of Physical Education, Recreation \& Dance; Reston Vol. 69, Iss. 2, (Feb 1998) : 21-23.

Febechen .2009. Menjadi Pribadi Unggul, Being a Higher Achiever. GPU. Jakarta.

Hafis Mu'addab, Pengertian Soft Skil dan Hard Skill, 2010, http://hafismuaddab.wordpress.com/tag/hard-skill/ (diunduh tanggal 5 September 2010) Republika Penerbit.

Leal, Dorothy J. Engaging students' minds and hearts: Authentic student assessment of character traits in literature Journal of Adolescent \& Adult Literacy; Hoboken Vol. 43, Iss. 3, (Nov 1999): 240-248. 
Mochtar Buchori, Charakter Building dan Pendidikan Kita, 2007 http://paramadina.wordpress.com/2007/03/04/character-building-dan- pendidikan-kita/ (diunduh tanggal 4 September 2010).

ProtoView; Handbook of Moral and Character Education, 2nd Edition Beaverton Vol. 1, Iss. 19, Beaverton: Ringgold Inc. (May 16, 2014). 